\title{
ANALISIS KELAYAKAN USAHA PERIKANAN TANGKAP MENGGUNAKAN ALAT TANGKAP GILL NET DAN PURSE SEINE DI KECAMATAN LEIHITU KABUPATEN MALUKU TENGAH PROVINSI MALUKU
}

\author{
Umar Tangke \\ Staf Pengajar Faperta UMMU-Ternate,e-mail: khakafart@yahoo.com
}

\begin{abstract}
ABSTRAK
Kecamatan Leihitu memiliki letak geografis yang menunjukan bahwa daerah tersebut dengan wilayah lautnya yang dominan memiliki potensi perikanan yang besar. Purse seine dan gill net merupakan jenis alat tangkap yang lebih dominan di gunakan oleh nelayan pada daerah tersebut. Apabila dilihat dari ketersediaan jumlah stok ikan di daerah tersebut maka perlu di lakukan pemanfaatan yang lebih optimal dengan meningkatkan jumlah unit alat tangkap pada daerah tersebut oleh sebab itu penelitian ini bertujuan untuk menentukan unit penangkapan ikan yang layak dikembangkan berdasarkan penilaian analisis aspek biologi, teknis, sosial dan ekonomis di wilayah Kecamatan Leihitu. Metode skoring dapat digunakan untuk penilaian kriteria yang mempunyai satuan berbeda. Skoring diberikan dari nilai terendah sampai nilai tertinggi. Untuk menilai suatu kriteria atau aspek digunakan nilai tukar, sehingga nilai tukar mempunyai standar yang sama. Unit usaha yang memperoleh nilai skor tertinggi lebih baik daripada yang lain, demikian pula sebaliknya. Hasil analisis aspek biologi, teknis, ekonomis dan sosial terhadap kedua unit penangkapan ikan di Kec. Leihitu, maka pengembangan unit penangkapan ikan yang bertujuan untuk meningkatkan produksi dan pendapatan nelayan serta efektif untuk dioperasikan adalah purse seine. Sedangkan untuk pengembangan unit penangkapan yang bertujuan agar mudah dijangkau dan diterima masyarakat nelayan tanpa mengabaikan faktor pemeliharaan dan peningkatan kelestarian sumberdaya perikanan adalah gillnet.
\end{abstract}

\section{Kata Kunci: Analisis kelayakan, Kec. Lihitu, Purse seine}

\section{PENDAHULUAN}

\subsection{Latar Belakang}

Wilayah pesisir dan kelautan Indonesia menyimpan berbagai macam sumberdaya, baik yang dapat diperbaharui maupun yang tidak dapat diperbaharui. Sumberdaya pesisir dan laut yang dapat diperbaharui seperti sumberdaya perikanan (perikanan tangkap, budidaya), mangrove, energi gelombang, pasang surut, angin dan Ocean Thermal Energy Conversion (OTEC) membutuhkan pengelolaan yang baik guna dimanfaatkan secara optimal. Kenyataan yang dapat kita lihat bahwa sektor perikanan dan kelautan tetap eksis dan bahkan terjadi peningkatan perolehan pendapatan bagi pengusaha di sektor ini ketika bangsa dilanda keterpurukan ekonomi dan krisis moneter yang berkepanjangan dimana nilai tukar rupiah jatuh pada level bawah terhadap dollar Amerika.

Pembangunan ekonomi perikanan dan kelautan dewasa ini mulai terlihat titik terang dalam kemajuannya, yang mana pada kabinet pemerintahan sekarang telah dibentuk suatu institusi (Kementrian Kelautan dan Perikanan/KKP) yang secara khusus menangani sektor perikanan dan kelautan yang diharapkan dapat menjadi katalisator dan dinamisator berkembangnya sektor ini.

Sejalan dengan program pemerintah dalam rangka meningkatkan produksi sektor perikanan dan kelautan maka peran nelayan di daerah memiliki arti penting sebagai tulang punggung pencapaian produksi ikan yang ditargetkan. Namun satu hal yang perlu diingat bahwa 
pemanfaatan secara optimal sumberdaya yang ada haruslah berwawasan lingkungan dengan tetap memperhatikan kelestarian sumberdaya tersebut. Keberadaan nelayan lokal dalam mengembangkan usahanya perlu mendapatkan perhatian karena usaha yang dilakukan umumnya masih bersifat sederhana/tradisional dimana daya jangkau nelayan dalam menangkap ikan masih terbatas di perairan pantai.

Menurut Barus et al (1991), produktifitas nelayan yang masih rendah ini pada umumnya diakibatkan oleh rendahnya ketrampilan dan pengetahuan serta penggunaan alat penangkapan maupun perahu yang masih sederhana, sehingga efektifitas dan efisiensi alat tangkap maupun perahu belum optimal. Keadaan ini berpengaruh terhadap pendapatan yang diterima nelayan yang relatif rendah, keadaan ekonomi dan kesejahteraan nelayan pada umumnya masih tertinggal bila dibandingkan dengan masyarakat petani atau masyarakat lainnya.

Upaya yang dapat dilakukan untuk meningkatkan taraf hidup atau pendapatan nelayan, antara lain dengan meningkatkan produksi hasil tangkapannya. Salah satu cara untuk meningkatkan produksi tersebut adalah dengan mengusahakan unit penangkapan yang produktif, yakni yang tinggi dalam jumlah dan nilai hasil tangkapannya. Selain itu, unit penangkapan tersebut haruslah bersifat ekonomis, efisien dan menggunakan teknologi yang sesuai dengan kondisi setempat serta tidak merusak kelestarian sumberdaya perikanan (Wisudo et al, 2002).

Kecamatan Leihitu berada di wilayah Kabupaten Maluku Tengah merupakan bagian dari provinsi Maluku memiliki potensi perikanan yang cukup menjanjikan, dimana potensi sumberdaya ikan yang dimiliki tersedia dan memberikan prospek yang cerah untuk dimanfaatkan. Strategi pembangunan perikanan di Maluku Tangah adalah upaya peningkatan produktifitas bagi nelayan setempat yang melakukan kegiatan usaha penangkapan ikan.

Kecamatan Leihitu memiliki letak geografis yang menunjukan bahwa daerah tersebut dengan wilayah lautnya yang dominan memiliki potensi perikanan yang besar. Data dari Statistik Perikanan Maluku menunjukan produksi perikanan pada tahun 2009 sebesar 429,892,2 ton (Dinas Perikanan Propinsi Maluku, 2010).

Untuk itu informasi mengenai kondisi nelayan lokal yang melakukan usaha penangkapan ikan sangatlah penting dalam rangka meningkatkan dan mengembangkan usaha mereka. Oleh sebab itu penelitian ini bertujuan untuk mengevaluasi alat tangkap yang digunakan oleh nelayan untuk menangkap ikan di perairan pesisir pulau Ambon dan laut Banda.

\subsection{Tujuan dan Kegunaan}

Penelitian ini bertujuan untuk menentukan unit penangkapan ikan yang layak dikembangkan berdasarkan penilaian analisis aspek biologi, teknis, sosial dan ekonomis di wilayah Kecamatan Leihitu.

\section{METODOLOGI PENELITIAN}

\subsection{Waktu dan Tempat}

Penelitian dilaksanakan di Kecamatan Leihitu Kabupaten Maluku Tengah Provinsi Maluku selama 2 bulan (Mei-Juni 2007)

\subsection{Metode Penelitian}

Penelitian ini mengunakan metode kuisioner yaitu suatu metode yang digunakan dengan cara mewawancarai secara langsung kepada nelayan pemilik (responden) dengan menggunakan daftar pertanyaan.

\subsubsection{Pengmabilan Data}

Data yang diperoleh dalam penelitian ini adalah data primer yang diperoleh dari nelayan pemilik usaha penangkapan ikan dengan cara melakukan wawancara langsung berdasarkan daftar pertanyaan (kuisioner). Data yang dikumpulkan dari usaha perikanan tangkap purse seine dan gillnet meliputi data investasi, produksi hasil tangkapan, musim penangkapan, teknik pengoperasian alat, tenaga kerja, lama operasi penangkapan, deskripsi alat penangkapan ikan, dan lain sebagainya.

\subsubsection{Analisis Data}

Data yang diperoleh dalam penelitian ini dilakukan analisis pada semua aspek yaitu aspek Biologi, Teknis, Sosial, dan Ekonomis dengan menggunakan formula:

\section{A. Aspek Biologi}

Analisis aspek biologi dilakukan dengan penilaian terhadap kriteria sebagai berikut :

(1) Lama waktu musim ikan (bulan)

(2) Lama waktu musim penangkapan ikan (bulan)

(3) Selektivitas alat penangkapan ikan (skor)

B. Aspek Teknis

Aspek teknis merupakan aspek yang berhubungan dengan pengoperasian alat penangkapan ikan, apakah alat tangkap tersebut efektif atau tidak bila dioperasikan. Kriteria yang digunakan dalam penilaian aspek teknis meliputi:

(1). Produksi per tahun $(\mathrm{kg})$

(2). Produksi per trip (kg) 
(3). Produksi per jam operasi $(\mathrm{kg})$

(4). Produksi per tenaga kerja $(\mathrm{kg})$

(5). Produksi per biaya investasi $(\mathrm{kg})$

C. Aspek Ekonomis

Analisis aspek ekonomis meliputi penilaian efisiensi secara ekonomi dan kelayakan finansial. Kriteria yang digunakan dalam penilaian efisiensi secara ekonomi adalah:

(1). Penerimaan kotor per tahun $(\mathrm{Rp})$

(2). Penerimaan kotor per trip (Rp)

(3). Penerimaan kotor per jam operasi ( $R p)$

(4). Penerimaan kotor per tenaga kerja (Rp)

(5). Penerimaan per biaya investasi $(\mathrm{Rp})$

Untuk menentukan lamanya waktu yang diperlukan agar modal yang tertanam pada suatu investasi dapat diperoleh kembali, dipergunakan analisis Payback of Period dengan formula :

Payback of Period $=\frac{\text { Invsetasi }(R p)}{\text { Pendapatan Bersih }(R p)} \times 1$ tahun

Sedangkan untuk mengetahui kapan keuntungan mulai diperoleh maka dilakukan analisis Break Even Point (Sigit, 1979) dengan formula:

$$
B E P=\frac{\text { BiayaTetap }(R p)}{1-\frac{\text { BiayaVariabel }(R p)}{\text { PendapatanTotal }(R p)}}
$$

Analisis finansial yang dilakukan bertujuan untuk melihat suatu usaha penangkapan ikan bersifat menguntungkan atau tidak serta prospek kelanjutan usaha tersebut. Menurut Kadariah et al (1978), analisis finansial dari suatu usaha dalam hal ini usaha penangkapan ikan dapat dihitung berdasarkan kriteria penilaian sebagai berikut:

\section{Net Present Value (NPV)}

Net Present Value merupakan selisih antara present value dari benefit dan present value dari biaya kotor yang dapat diformulasikan sebagai berikut:

$$
N P V=\sum_{t=1}^{n} \frac{B_{t}-C_{t}}{(1+i)^{t}}
$$

Dimana:

$$
\begin{aligned}
& \mathrm{B}_{\mathrm{t}}=\text { Benefit kotor } \\
& \mathrm{Ct}=\text { Biaya kotor } \\
& \mathrm{N}=\text { Nilai umur ekonomis usaha } \\
& \mathrm{I}=\text { Tingkat suku bunga }
\end{aligned}
$$

Usaha penangkapan ikan dapat dilanjutkan apabila NPV >0, artinya usaha tersebut menguntungkan. Bila NPV $<0$ maka usaha penangkapan ikan tersebut kerugian. Apabila $\mathrm{NPV}=0$, berarti usaha penangkapan tersebut tidak mendapat keuntungan dan tidak pula mengalami kerugian.

\section{Internal Rate of Return (IRR)}

Internal Rate of Return adalah nilai dari suku bunga yang membuat NPV dari suatu usaha penangkapan ikan sama dengan nol, yang dapat diformulasikan sebagai berikut:

$$
\mathrm{NPV}=\sum_{t=1}^{n} \frac{B_{t}-C_{t}}{(1+\mathrm{IRR})^{t}}
$$

Internal Rate of Return dapat pula dianggap sebagai keuntungan atas investasi bersih dari suatu usaha dan dapat diformulasikan sebagai berikut:

$$
\text { IRR }=i^{\prime}+\frac{N P V^{\prime}}{N^{\prime} V^{\prime}-N^{\prime \prime \prime}}\left(i^{\prime \prime \prime}-i^{\prime \prime}\right)
$$

Dimana:

i' = Tingkat suku bunga pada NPV positif

i', = Tingkat suku bunga pada NPV negatif

NPV' = Hasil NPV positif

NPV"= Hasil NPV negatif

Apabila nilai IRR > i, artinya usaha tersebut dapat mengembalikan nilai suku bunga setiap tahunnya dan usaha penangkapan tersebut dapat dilanjutkan. Tetapi bila nilai IRR $<$ I, maka usaha penangkapan tersebut mengalami kerugian, karena tidak dapat mengembalikan nilai suku bunga tiap tahunnya atau dengan kata lain usaha tersebut tidak dapat dilanjutkan. Sedangkan untuk nilai $I R R=0$, berarti usaha tersebut tidak mendapat keuntungan dan tidak pula mengalami kerugian.

\section{Net benefit-cost ratio (Net B/C)}

Net Benefit-Cost Ratio adalah perbandingan antara present value total dari benefit bersih dalam tahun-tahun dimana benefit bersih itu bersifat positif dengan present value total dari biaya bersih dalam tahun-tahun dimana benefit bersih bersifat negatif, yang dapat dirumuskan sebagai berikut:

$$
\begin{aligned}
& \text { Net } B / C=\frac{\sum_{\mathrm{t}=1}^{\mathrm{n}} \frac{\mathrm{B}_{\mathrm{t}}-\mathrm{C}_{\mathrm{t}}}{(1+\mathrm{i})^{\mathrm{t}}}}{\sum_{\mathrm{t}=1}^{\mathrm{n}} \frac{\mathrm{C}_{\mathrm{t}}-\mathrm{B}_{\mathrm{t}}}{(1+\mathrm{i})^{\mathrm{t}}}} \\
& \left(B_{t}-C_{t}>0\right) \\
& \left(B_{t}-C_{t}<\mathrm{O}\right)
\end{aligned}
$$


Usaha penangkapan ikan dapat dilanjutkan apabila nilai dari Net $\mathrm{B} / \mathrm{C}>1$ artinya usaha tersebut mendatangkan keuntungan sebaliknya bila nilai Net $\mathrm{B} / \mathrm{C}<1$, berarti usaha tersebut tidak dapat dilanjutkan karena mengalami kerugian. Apabila nilai Net $\mathrm{B} / \mathrm{C}=0$, berarti jumlah penerimaan sama dengan jumlah pembiayaan atau dengan kata lain usaha tersebut tidak mengalami keuntungan maupun kerugian

D. Aspek Sosial

Pendekatan yang dilakukan untuk menganalisis aspek sosial dari suatu jenis alat penangkapan ikan dengan menggunakan kriteria sebagai berikut :

(1) Penyerapan tenaga kerja per jenis alat penangkapan ikan (orang).

(2) Pendapatan nelayan per jenis alat tangkap per orang per tahun (Rp)

(3) Kemampuan nelayan dalam menjangkau investasi unit penangkapan ikan (\%).

\section{E. Metode Skoring}

Untuk menentukan jenis teknologi penangkapan ikan yang layak dikembangkan dilakukan dengan metode skoring (Wisudo et al, 1994). Metode skoring dapat digunakan untuk penilaian kriteria yang mempunyai satuan berbeda. Skoring diberikan dari nilai terendah sampai nilai tertinggi. Untuk menilai suatu kriteria atau aspek digunakan nilai tukar, sehingga nilai tukar mempunyai standar yang sama. Unit usaha yang memperoleh nilai skor tertinggi lebih baik daripada yang lain, demikian pula sebaliknya. Untuk menghindari pertukaran yang terlalu banyak, maka digunakan fungsi nilai yang menggambarkan preferensi pengambilan keputusan dalam menghadapi kriteria majemuk.

Standardisasi dengan fungsi nilai dapat digunakan dengan menggunakan formula dari Mangkusubroto dan Trisnadi (1985), sebagai berikut:

$$
\begin{aligned}
& V(X)=\frac{X-X_{0}}{X_{1}-X_{0}} \ldots \\
& V(A)=\sum_{i=1}^{n} V_{i}\left(X_{i}\right)
\end{aligned}
$$

Dimana:
i
$\mathrm{V}(\mathrm{X})$
$\mathrm{X}$
$\mathrm{X}_{1}$
$\mathrm{X}_{0}$
$\mathrm{V}_{(\mathrm{A})}$
$1,2,3 \ldots \ldots \ldots \ldots n$
Fungsi nilai dari variabel $\mathrm{X}$
Nilai variabel $\mathrm{X}$
Nilai tertinggi pada kriteria $\mathrm{X}$
Nilai terendah pada kriteria $X$
$\mathrm{Vi}(\mathrm{Xi})$ : Fungsi nilai dari alternatif pada kriteria ke-1

Kriteria $\mathrm{V}$ adalah fungsi nilai yang mencerminkan preferensi pengambilan keputusan, maka alternatif yang terbaik adalah alternatif yang memberikan nilai $\mathrm{V}(\mathrm{X})$ tertinggi.

\section{HASIL DAN PEMBAHASAN \\ 3.1. Gambaran Umum Alat Penangkapan Ikan}

Alat penangkapan ikan adalah sarana dan perlengkapan atau benda-benda lainnnya yang dipergunakan untuk menangkap ikan (Dirjen Perikanan, 1996). Ada dua jenis alat penangkapan ikan yang dioperasikan oleh sebagian besar nelayan di Kecamatan Leihitu insang) dan purse seine (jaring kantong).

\subsubsection{Gillnet (jaring insang)}

Gillnet (jaring insang) adalah alat tangkap yang direntangkan di suatu perairan pada kedalaman tertentu dan ukuran mata jaring tertentu, sehingga ikan yang menabrak jaring akan terjerat atau terbelit pada mata jaring. Jaring insang yang digunakan oleh nelayan di Kec. Leihitu umumnya berbentuk empat persegi panjang dengan ukuran panjang jaring $175 \mathrm{~m}$, lebar jaring $1,5 \mathrm{~m}$, dan ukuran mata jaring sebesar 3" (25 mm) yang bertujuan untuk menangkap ikan-ikan demersal. Bahan jaring terbuat dari bahan monofilamen dan tali ris serta tali pelampung yang digunakan terbuat dari bahan polyethylene (PE). Jenis pelampung yang digunakan ada dua jenis yaitu pelampung tanda yang berfungsi untuk memberikan tanda dan pelampung yang melekat pada tubuh jaring yang berfungsi untuk mengangkat tali ris atas agar gillnet dapat berdiri tegak. Pemberat yang digunakan berfungsi untuk menenggelamkan seluruh alat ke dasar perairan. Daya tahan alat yang digunakan untuk beroperasi bisa mencapai 10 tahun dengan perawatan yang baik. Dengan melihat spesifikasi yang ada dan ikan-ikan yang menjadi tujuan penangkapan maka gillnet yang digunakan oleh nelayan Kec. Leihitu termasuk dalam kategori gillnet dasar (bottom gillnet).

\subsubsection{Purse Seine (jaring kolor)}

Sadhori (1985), menyatakan bahwa purse seine biasanya disebut jaring kantong karena bentuk jaring tersebut waktu dioperasikan menyerupai kantong. Purse seine kadang-kadang juga disebut jaring kolor karena pada bagian bawah jaring (tali ris bawah) dilengkapi dengan tali kolor tersebut.

Purse seine yang digunakan oleh nelayan untuk menangkap ikan di perairan Kec. Leihitu umumnya berbentuk empat persegi panjang dengan ukuran panjang $500 \mathrm{~m}$, lebar $35 \mathrm{~m}$, dan 
besarnya mesh size (mata jaring) 1" (25 mm). Bahan jaring terbuat dari bahan multifilamen dengan nomor 210 D/9. Pelampung yang digunakan ada dua jenis yaitu pelampung tanda yang berfungsi sebagai tanda dan pelampung yang berfungsi untuk memberikan daya apung pada alat. Pelampung ini terbuat dari bahan sintesis yaitu Poly Vinyl Chloridae (PVC) dan beerbentuk bola. Tali yang digunakan pada alat tangkap ini seperti tali ris atas, tali ris bawah, tali pelampung, dan tali pemberat terbuat dari bahan polyethylene (PE). Sedangkan bahan pemberat terbuat dari bahan timah. Daya tahan dari alat ini bisa mencapai 20 tahun dengan perawatan dan penanganan yang baik.

Purse seine termasuk alat tangkap yang produktif dan sifatnya aktif yaitu mencari gerombolan ikan kemudian dilakukan proses pelingkaran (setting) sehingga ikan-ikan akan terkepung baik dari arah bawah, atas, maupun samping. Ikan-ikan yang menjadi tujuan penangkapan dari alat tangkap ini adalah jenisjenis ikan pelagis yang membentuk schooling.

\subsection{Organisasi Usaha Perikanan Tangkap}

Usaha perikanan tangkap yang dilakukan nelayan di Kecamatan Leihitu masih terbatas pada usaha yang sifat kepemilikannya secara individual dan belum ada lembaga seperti koperasi yang secara resmi menaungi mereka. Namun bila ditinjau dari status kepemilikan dan orang-orang yang bekerja maka dapat diketahui secara jelas tingkatan organisasi usahanya. Gambar secara sederhana organisasi usaha perikanan tangkap khususnya yang menggunakan alat tangkap purse seine di Kecamatan Leihitu pada Gambar 1.

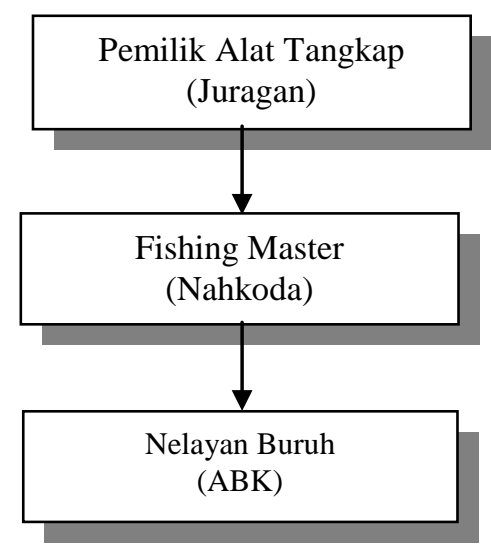

Gambar 1. Skema Organisasi Usaha Perikanan Tangkap Purse Seine di Kec. Leihitu Kabupaten Maluku Tengah
Usaha perikanan tangkap gillnet yang menjadi sampel dalam penelitian ini tidak memiliki tingkatan organisasi usaha, disebabkan pemilik alat tangkap berfungsi sebagai nelayan yang secara langsung melakukan kegiatan penangkapan ikan. Namun fungsinya sebagai nelayan hanya dijadikan sebagai pekerjaan sambilan setelah melakukan pekerjaan rutinitasnya sebagai tenaga pendidik pada salah satu sekolah di Kec. Leihitu Kabupaten Maluku Tengah.

\subsubsection{Perencanaan Operasi Penangkapan Ikan}

Perencanaan operasi penangkapan di mulai dari persiapan diantaranya :

a. Persiapan bahan bakar

b. Lampu-lampu dan minyak

c. Alat-alat navigasi (kompas, peta laut, teropong)

d. Persiapan-persiapan mesin (peralatan motor)

e. Persiapan pengaturan alat tangkap

Diantara persiapan di atas yang berhubungan erat dengan masalah operasi penangkapan adalah persiapan pengaturan alat tangkap di atas kapal. Pengaturan alat tangkap ini sangat menentukan posisi penawuran alat dan kerja dari $\mathrm{ABK}$, sehingga penataan alat di atas dek kapal harus teratur dan letaknya (posisi kanan, tengah atau kiri) disesuaikan dengan kebiasaan nelayan ataupun berpedoman pada arah putaran baling-baling kapal. Untuk alat tangkap gillnet biasanya tidak terlalu sukar dalam melakukan penataan, karena ukurannya yang kecil. Berbeda dengan gillnet, untuk alat purse seine penataan harus dilakukan dengan cermat karena selain ukurannya yang besar juga pengaturan pemberat dan pelampung harus pada posisi yang siap pakai. Apabila perlengkapan yang dibutuhkan telah terpenuhi maka para nelayan segera bertolak menuju fishing ground.

\subsubsection{Fishing Ground}

Daerah penangkapan ikan (fishing ground) ialah suatu daerah perairan tempat ikan berkumpul dimana penangkapan ikan dapat dilakukan. Daerah penangkapan dibedakan menurut sifat perairan, jenis ikan yang ditangkap dan alat tangkap yang digunakan. Fishing ground bagi nelayan yang mengoperasikan alat tangkap purse seine adalah perairan pesisir pulau Ambon dan laut Banda pada kedalaman perairan sekitar 100 meter dengan dasar perairan lumpur dan berpasir. Jarak yang ditempuh nelayan dari fishing base ke fishing ground sekitar 3 mil.

Sama halnya dengan purse seine, alat tangkap gillnet yang dioperasikan oleh nelayan di Kec. Leihitu melakukan penangkapan di 
sekitar perairan pesisir pulau Ambon dan Laut Banda pada kedalaman perairan diatas 30 meter dengan dasar perairan berpasir dan lumpur. Jarak fishing base ke fishing ground sekitar 3 mil.

Khusus bagi alat tangkap purse seine penentuan fishing ground antara lain: perairan tersebut terdapat ikan hidup yang bergerombol (Schooling) dan kedalaman perairan lebih dalam daripada alat yang akan dipergunakan. Purse seine yang digunakan nelayan di Kec. Leihitu tidak menggunakan alat bantu penangkapan melainkan dengan cara mencari gerombolan ikan. Dengan demikian pencarian fishing ground bebas dengan dengan menuruti kebiasaan berkumpulnya ikan-ikan dalam suatu saat tertentu. Untuk itu faktor pengalaman nelayan sangat dibutuhkan dalam penentuan daerah penangkapan dan pengoperasian alat. Berbeda dengan purse seine, alat tangkap gillnet memiliki beberapa persyaratan daerah penangkapan yang baik untuk melakukan operasi. Sadhori (1985), mengemukakan ada beberapa persyaratan daerah penangkapan yang baik bagi gillnet adalah :

1. Bukan daerah alur pelayaran umum

2. Untuk gillnet dasar, dasar perairan tidak berkarang

3. Arus arahnya beraturan dan paling kuat sekitar 4 knot

4. Untuk gillnet permukaan dalam perairan sekitar 20-30 meter

5. Untuk gillnet pertengahan (midwater gillnet) dalam perairan dapat lebih dari 50 meter.

Berdasarkan keterangan diatas maka gillnet yang dioperasikan oleh nelayan di Kec. Leihitu masuk kategori gillnet dasar.

\subsection{3.. Hasil Tangkapan}

Penangkapan ikan dengan alat tangkap purse seine yang dilakukan oleh nelayan Kec. Leihitu menggunakan sistim pengejaran terhadap gerombolan ikan. Jenis ikan yang menjadi tujuan penangkapan adalah ikan-ikan pelagis yang membentuk schooling. Pencarian gerombolan ikan biasanya dengan menggunakan pengalaman yang telah diperoleh pada penangkapanpenangkapan sebelumnya yaitu dengan cara melihat tanda-tanda alam. Tanda-tanda alam itu seperti perubahan permukaan air laut karena gerombolan ikan berenang dekat permukaan air, ikan-ikan kecil yang melompat di permukaan dan kawanan burung-burung yang terbang dan menukik di permukaan air laut. Dengan demikian maka faktor pengambilan keputusan oleh fishing master sangat menentukan berhasilnya operasi penangkapan yang juga berpengaruh pada jumlah hasil tangkapan yang diperoleh.

Jenis hasil tangkapan yang umumya tertangkap dengan alat ini antara lain: ikan Cakalang (Katsuwonus pelamis), ikan Layang (Decapterus russelli), ikan Kembung lelaki (Rastrelliger brachysoma), dan ikan selar (Sardinella fimbriata). Jumlah hasil tangkapan per trip yang dihasilkan oleh alat tangkap purse seine di Kec. Leihitu sebesar 566,7 kg dan dalam setahun sebesar $65.400 \mathrm{~kg}$.

Penangkapan ikan dengan menggunakan alat tangkap gillnet umumnya dilakukan pada waktu malam hari terutama waktu gelap bulan. Dalam satu malam bila bulan gelap penuh operasi penangkapan dapat dilakukan sampai dua kali karena dalam sekali penurunan alat, gillnet didiamkan terpasang dalam perairan sampai kirakira selama 3-5 jam (Sadhori, 1984). Hasil tangkapan yang diperoleh dengan menggunakan alat tangkap gillnet biasanya dalam jumlah yang sedikit bila dibandingkan dengan hasil yang diperoleh purse seine karena ukuran alat yang kecil dan pengoperasiannya yang pasif (menunggu ikan yang menabrak jaring tersebut dan terbelit). Jenis hasil tangkapan yang diperoleh nelayan di Kec. Leihitu dengan menggunakan gillnet seperti: ikan kerapu (Cromileptes altivelis), ikan Beronang (Siganus javus), ikan Kwee (Carangoides ciliarus), ikan Kembung Lelaki (Rastrelliger brachysoma), dan Ikan saku (Tylosurus crocodilus) dan lain sebagainya. Jumlah hasil tangkapan (produksi) dari alat tangkap gillnet per trip sebesar $48,3 \mathrm{~kg}$ dan dalam setahun sebesar $8.694 \mathrm{~kg}$.

\subsubsection{Pemasaran Hasil Tangkapan}

Pemasaran atau tataniaga merupakan suatu proses daripada pertukaran yang mencakup serangkaian kegiatan yang tertuju untuk memindahkan barang-barang atau jasa-jasa dari sektor produksi ke sektor konsumsi (Hanafiah dan Saefuddin, 1986). Lebih lanjut dikatakan tataniaga hasil perikanan mempunyai sejumlah ciri, diantaranya sebagai berikut:

(1) Sebagian besar dari hasil perikanan berupa bahan makanan yang dipasarkan diserap oleh konsumen akhir secara relatif stabil sepanjang tahun sedangkan penawarannya sangat tergantung kepada produksi yang sangat dipengaruhi oleh keadaan iklim.

(2) Saluran tataniaga hasil perikanan pada umumnya terdiri dari : produsen, pedagang perantara sebagai pengumpul, wholesaler (grosir), pedagang eceran dan konsumen. 
(3) Kedudukan terpenting dalam tataniaga hasil perikanan terletak pada pedagang pengumpul dalam fungsinya sebagai pengumpul hasil, berhubung daerah produksi terpencar-pencar, skala produksi kecil-kecil dan produksinya berlangsung musiman.

(4) Tataniaga hasil perikanan tertentu pada umumnya bersifat musiman, karena pada umumnya produksi berlangsung musiman, dan ini jelas terlihat pada perikanan laut.

Pemasaran atau tataniaga hasil perikanan yang dilakukan oleh nelayan di Kec. Leihitu biasanya dijual langsung pada pengumpul (jibujibu) dalam bentuk segar. Hasil tangkapan yang dipasarkan umumnya untuk memenuhi kebutuhan lokal masyarakat setempat terhadap permintaan produk ikan dan dijual secara bebas. Khusus bagi hasil tangkapan yang diperoleh dengan menggunakan alat tangkap purse seine apabila produksinya melimpah biasanya sebagian dipasarkan keluar daerah yaitu di kota Ambon. Apabila hasil tangkapan dipasarkan di luar daerah (Ambon), maka biaya pengangkutan harus dikeluarkan oleh nelayan dalam memasarkan produknya. Biaya pengangkutan yang dikeluarkan oleh nelayan yang menggunakan alat tangkap purse seine dalam setahun sebesar Rp. 10.920.000,- . Berikut ini dapat dilihat rantai pemasaran hasil perikanan yang berlangsung di Kec. Leihitu Kabupaten Maluku Tengah :

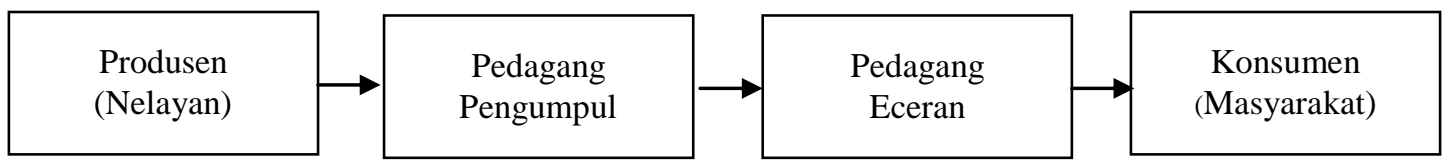

Gambar 2. Alur Pemasaran Hasil Tangkapan Ikan Oleh Nelayan di Kec. Leihitu Kab. Maluku Tengah

\subsection{Determinasi Usaha Perikanan Tangkap}

Perikanan tangkap menurut Direktorat Jenderal Perikanan (Monintja, 1995) adalah kegiatan ekonomi dalam bidang penangkapan secara bebas. Defenisi tersebut secara jelas menunjukan bahwa kegiatan penangkapan ikan yang dimaksud adalah bertujuan untuk mendapatkan keuntungan baik secara finansial, maupun untuk memeperoleh nilai tambah lainnya, seperti penyerapan tenaga kerja, pemenuhan kebutuhan terhadap protein hewani, devisa serta pendapatan negara lainnya. Usaha perikanan tangkap yang dilakukan nelayan di Kec. Leihitu Kabupaten Maluku Tengah dianalisis berdasarkan aspek biologi, teknis, ekonomis dan sosial untuk menentukan teknologi penangkapan ikan pilihan yang layak dikembangkan di daerah tersebut.

\subsubsection{Analisis Aspek Biologi}

Penggunaan kriteria dalam penilaian aspek biologi terhadap kedua jenis unit penangkapan ikan di Kec. Leihitu Kabupaten Maluku Tengah adalah : lama musim ikan, lama waktu musim penangkapan ikan, dan selektifitas alat penangkapan ikan. Penilaian terhadap masingmasing kriteria tersebut dan urutan prioritas dari setiap unit penangkapan ikan dapat dilihat pada Tabel 1.

Penilaian pada kriteria lama musim ikan menempatkan purse seine pada urutan prioritas pertama dan jaring insang pada urutan kedua. Penilaian terhadap lama waktu musim penangkapan ikan menempatkan purse seine pada urutan prioritas pertama dan gillnet pada urutan kedua. Sedangkan terhadap penilaian selektivitas alat penangkapan ikan menempatkan gillnet pada urutan prioritas pertama dan purse seine pada urutan kedua.

Hasil penilaian aspek biologi secara keseluruhan setelah distandardisasi dengan menggunakan fungsi nilai, dapat dilihat pada Tabel 2. Urutan prioritas pertama adalah purse seine dan urutan kedua adalah gillnet.

Berdasarkan penilaian aspek biologi secara keseluruhan dengan menggunakan fungsi nilai, purse seine menempati urutan prioritas pertama, karena memiliki jumlah nilai tertinggi. Hal ini dikarenakan musim ikan yang menjadi tujuan penangkapan dan lamanya waktu penangkapan paling tinggi dibandingkan dengan gillnet, kendati nilai selektifitas alat ini rendah. 
Tabel 1. Nilai Masing-masing Kriteria dalam Aspek Biologi dan Urutan Proritas dari Setiap Unit Penangkapan Ikan di Kec. Leihitu

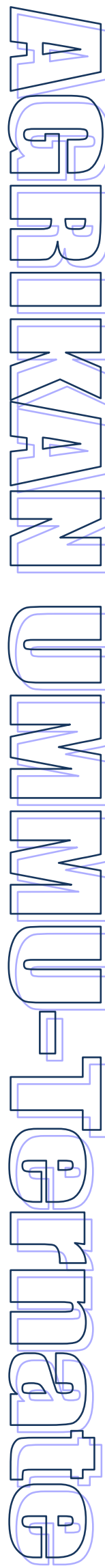

\begin{tabular}{|c|c|c|c|c|c|c|c|}
\hline \multirow{2}{*}{\multicolumn{2}{|c|}{ Unit Penangkapan lkan }} & \multicolumn{6}{|c|}{ Kriteria } \\
\hline & & $X_{1}$ & UP & $X_{2}$ & UP & $X_{3}$ & UP \\
\hline Gillnet & & 10 & 2 & 9 & 2 & 4 & 1 \\
\hline Purse Seine & & 12 & 1 & 11 & 1 & 2 & 2 \\
\hline $\begin{array}{r}\text { Keterangan: } \\
\text { X1 } \\
\text { X2 } \\
\text { X3 } \\
\text { UP }\end{array}$ & $\begin{array}{l}=\text { Lama } \\
=\text { Lama } \\
=\text { Selek } \\
=\text { Uruta }\end{array}$ & $\begin{array}{l}\text { gkap } \\
\text { pan ik }\end{array}$ & ulan) & & & & \\
\hline
\end{tabular}

Tabel 2. Penilaian Aspek Biologi Secara Keseluruhan dengan Fungsi Nilai dari Setiap Unit Penangkapan Ikan di Kec. Leihitu

\begin{tabular}{|c|c|c|c|c|c|}
\hline \multirow{2}{*}{ Unit Penangkapan Ikan } & \multicolumn{3}{|c|}{ Kriteria } & \multirow{2}{*}{$V(X)$} & \multirow{2}{*}{ UP } \\
\hline & $V\left(X_{1}\right)$ & $V\left(X_{2}\right)$ & $\mathrm{V}\left(\mathrm{X}_{3}\right)$ & & \\
\hline Gillnet & 0 & 0 & 0 & 0 & 2 \\
\hline Purse Seine & 1 & 1 & 1 & 3 & 1 \\
\hline
\end{tabular}

\subsubsection{Analisis Aspek Teknis}

Hasil yang diperoleh dari penilaian terhadap setiap kriteria dan urutan prioritas dari setiap unit penangkapan ikan dapat dilihat pada Tabel 3, Penilaian aspek teknis terhadap produksi per tahun menempatkan purse seine pada urutan prioritas pertama dan gillnet pada urutan kedua. Penilaian terhadap kriteria produksi per trip, produksi per jam operasi dan produksi per tenaga kerja menempatkan purse seine pada urutan pertama dan gillnet pada urutan kedua. Sedangkan penilaian terhadap kriteria produksi per biaya investasi menempatkan purse seine pada urutan prioritas pertama dan gillnet pada urutan prioritas kedua.

Hasil penilaian aspek teknis setelah distandardisasi dengan menggunakan fungsi nilai terhadap dua jenis alat penangkapan ikan di Kec. Leihitu, dapat dilihat pada Tabel 4. Urutan prioritas pertama adalah purse seine dan urutan kedua adalah gillnet.

Hasil penilaian aspek teknis secara keseluruhan dengan menggunakan fungsi nilai, unit penangkapan ikan purse seine menempati urutan prioritas pertama untuk dikembangkan, karena purse seine dinilai cukup efektif untuk meningkatkan produksi hasil tangkapan dan terbukti, produksi purse seine paling tinggi bila dibandingkan dengan alat tangkap gillnet. Salah satu faktor penyebabnya diduga karena ukuran kapal yang digunakan oleh nelayan dalam mengoperasikan purse seine cukup besar dan mempunyai kemampuan untuk mencari daerah jelajah penangkapan ikan yang umumnya jauh dari pantai.
Produksi per trip, dan produksi per jam operasi yang dihasilkan oleh unit penangkapan ikan purse seine sebesar 566,7 $\mathrm{Kg}$ dan $70,84 \mathrm{~kg}$ lebih tinggi bila dibandingkan dengan gillnet. Hal ini disebabkan waktu melaut (trip) lebih banyak dan jangka waktu dalam mengoperasikan alat tangkap lebih lama bila dibandingkan dengan gillnet. Khusus untuk nelayan yang mengoperasikan gillnet, kegiatan penangkapan ikan bukanlah pekerjaan utamanya melainkan merupakan pekerjaan sambilan diluar pekerjaan tetapnya. Berbeda dengan nelayan yang mengoperasikan alat tangkap purse seine yang merupakan mata pencaharian utama sehingga sebagian besar waktunya digunakan untuk melaut.

Bila dilihat dari biaya investasi, maka purse seine dinilai lebih tinggi daripada gillnet karena memiliki nilai yang tinggi daripada gillnet. Jumlah tenaga kerja yang pada unit penangkapan ikan purse seine lebih banyak daripada gillnet yaitu berjumlah 15 0rang. Penggunaan tenaga kerja yang cukup banyak ini dimbangi dengan produksi hasil tangkapan yang tinggi, sehingga produksi per tenaga kerja dinilai paling baik bila dibandingkan dengan gillnet. Selain itu dalam pengoperasiannya purse seine memang membutuhkan tenaga yang banyak karena ukuran alat tangkap yang cukup besar dan membutuhkan penanganan yang baik. Lain halnya dengan gillnet yang dapat dioperasikan oleh satu orang karena alat ini cukup praktis dan tidak terlalu sulit dalam melakukan setting maupun hauling pada pengoperasiannya. 


\subsubsection{Analisis Aspek Ekonomis}

Penilaian aspek ekonomi meliputi penilaian efisiensi secara ekonomi dan kelayakan finansial. Penilaian aspek ekonomis dari dua jenis alat tangkap yang telah dilakukan analisis dapat dilihat hasilnya pada Tabel 5. Berdasarkan penilaian terhadap masing-masing kriteria dalam efisiensi secara ekonomi, diperoleh bahwa urutan prioritas pada kriteria pendapatan pendapatan kotor per trip sama dengan urutan pada kriteria pendapatan kotor per jam kerja operasi, yaitu purse seine berada pada urutan pertama dan gillnet pada urutan kedua.
Penilaian terhadap pendapatan kotor per tahun menempatkan purse seine pada urutan prioritas pertama sedangkan pada urutan kedua adalah gillnet. Penilaian pada kriteria pendapatan kotor per tenaga kerja menempatkan purse seine pada urutan pertama dan gillnet pada urutan kedua. Hasil penilaian dengan menggunakan fungsi nilai terhadap kelima kriteria dalam efisiensi secara ekonomi dapat dilihat pada Tabel 6. Purse seine menempati urutan pertama dan gillnet pada urutan kedua.

Tabel 3. Nilai Masing-masing Kriteria dalam Aspek Teknis dan Urutan Prioritas dari Setiap Unit Penangkapan Ikan di Kec. Leihitu

\begin{tabular}{|c|c|c|c|c|c|c|c|c|c|c|c|c|}
\hline \multirow{2}{*}{\multicolumn{3}{|c|}{ Unit Penangkapan Ikan }} & \multicolumn{10}{|c|}{ Kriteria } \\
\hline & & & $X_{1}$ & UP & $\mathrm{X}_{2}$ & UP & $\mathbf{X}_{3}$ & UP & $\mathrm{X}_{4}$ & UP & $X_{5}$ & UP \\
\hline \multicolumn{3}{|l|}{ Gill Net } & 42.075 & 2 & 212,5 & 2 & 32,42 & 1 & 53,125 & 2 & 0,00066 & 2 \\
\hline \multicolumn{3}{|l|}{ Purse Seine } & 87.584 & 1 & 1990,5 & 1 & 13,82 & 2 & 284,36 & 1 & 0,00088 & 1 \\
\hline \multicolumn{13}{|l|}{ Keterangan: } \\
\hline $\mathrm{X} 1$ & $=$ & \multicolumn{11}{|c|}{ Produksi per tahun $(\mathrm{kg})$} \\
\hline $\mathrm{X} 2$ & $=$ & \multicolumn{11}{|c|}{ Produksi per trip $(\mathrm{kg})$} \\
\hline X3 & $=$ & \multicolumn{11}{|c|}{ Produksi per jam kerja operasi (kg) } \\
\hline X4 & $=$ & \multicolumn{11}{|c|}{ Produksi per tenaga kerja $(\mathrm{kg})$} \\
\hline$\times 5$ & $=$ & \multicolumn{11}{|c|}{ Produksi per biaya investasi (kg) } \\
\hline
\end{tabular}

Tabel 4. Penilaian Aspek Teknis Secara Keseluruhan dengan Fungsi Nilai dari Setiap Unit Penangkapan Ikan di Kec. Leihitu

\begin{tabular}{|c|c|c|c|c|c|c|c|}
\hline \multirow{2}{*}{ Unit Penangkapan Ikan } & \multicolumn{5}{|c|}{ Kriteria } & \multirow{2}{*}{$\mathrm{V}(\mathrm{X})$} & \multirow{2}{*}{ UP } \\
\hline & $V\left(X_{1}\right)$ & $V\left(X_{2}\right)$ & $V\left(X_{3}\right)$ & $\mathrm{V}\left(\mathrm{X}_{4}\right)$ & $V\left(X_{5}\right)$ & & \\
\hline Gill Net & 0 & 0 & 1 & 0 & 0 & 1 & 2 \\
\hline Purse Seine & 1 & 1 & 0 & 1 & 1 & 4 & 1 \\
\hline
\end{tabular}

Tabel 5. Nilai Masing-masing Kriteria dalam Efisiensi Ekonomi dan Urutan Prioritas dari Setiap Unit Penangkapan Ikan di Kec. Leihitu

\begin{tabular}{|c|c|c|c|c|c|c|c|c|c|c|}
\hline \multirow{2}{*}{$\begin{array}{c}\text { Unit Penangkapan } \\
\text { Ikan }\end{array}$} & \multicolumn{10}{|c|}{ Kriteria } \\
\hline & $X_{1}$ & UP & $X_{2}$ & UP & $X_{3}$ & UP & $X_{4}$ & UP & $X_{5}$ & UP \\
\hline Gill Net & 140.951 .250 & 2 & 711.875 & 2 & $118.645,83$ & 1 & $177.968,75$ & 2 & 1,153 & 2 \\
\hline Purse Seine & 262.746 .000 & 1 & 5.971 .500 & 1 & $41.468,75$ & 2 & $853.071,43$ & 1 & 1,262 & 1 \\
\hline \multicolumn{11}{|l|}{ Keterangan : } \\
\hline $\mathrm{X} 1$ & \multicolumn{10}{|c|}{ Pendapatan kotor per tahun (Rp) } \\
\hline X2 & \multicolumn{10}{|c|}{ Pendapatan kotor per trip $(\mathrm{Rp})$} \\
\hline $\mathrm{X} 3$ & \multicolumn{10}{|c|}{ Pendapatan kotor per jam kerja operasi (Rp) } \\
\hline X4 & \multicolumn{10}{|c|}{ Pendapatan kotor per tenaga kerja (Rp) } \\
\hline X5 & \multicolumn{10}{|c|}{ Pendapatan kotor per biaya investasi (Rp) } \\
\hline
\end{tabular}

Tabel 6. Penilaian Efisiensi Ekonomi Secara Keseluruhan dengan Fungsi Nilai dari Setiap Unit Penangkapan Ikan di Kec. Leihitu

\begin{tabular}{|c|c|c|c|c|c|c|c|}
\hline \multirow{2}{*}{ Unit Penangkapan Ikan } & \multicolumn{5}{|c|}{ Kriteria } & \multirow{2}{*}{$V(X)$} & \multirow{2}{*}{ UP } \\
\hline & $V\left(X_{1}\right)$ & $V\left(X_{2}\right)$ & $V\left(X_{3}\right)$ & $V\left(X_{4}\right)$ & $V\left(X_{5}\right)$ & & \\
\hline Gill Net & 0 & 0 & 1 & 0 & 0 & 1 & 2 \\
\hline Purse Seine & 1 & 1 & 0 & 1 & 1 & 4 & 1 \\
\hline
\end{tabular}


Penilaian terhadap masing-masing kriteria dalam kelayakan finansial, Net Present Value (NPV), Net Benefit-Cost Ratio (Net B/C) dan Internal Rate Of Return (IRR) saat discount faktor sebesar $15 \%$ pada setiap unit penangkapan ikan di Kec. Leihitu dapat dilihat pada Tabel 7.

Berdasarkan penilaian aspek ekonomi dan kelayakan finansial, diperoleh bahwa pengembangan usaha unit penangkapan purse seine dinilai lebih menguntungkan dibandingkan dengan alat tangkap lainnya. Hal ini dilihat dari produktifitas purse seine yang tinggi, sehingga menghasilkan pendapatan kotor per tahun, pendapatan kotor per trip maupun pendapatan kotor per jam kerja operasi yang tinggi. Sedangkan untuk pendapatan kotor per nelayan diperoleh nilai yang tinggi pada unit penangkapan gillnet dimana hasil yang diperoleh sebesar Rp 144.900,-. Hal ini disebabkan karena tenaga kerja yang digunakan dalam pengoperasian alat tangkap gillnet hanya satu orang yang juga sekaligus merangkap sebagai pemilik dan nahkoda. Untuk unit penangkapan purse seine pendapatan kotor per nelayan sebesar Rp 113.340,- lebih kecil jika dibandingkan dengan unit penangkapan gillnet, dikarenakan penggunaan tenaga kerja yang cukup banyak dalam mengoperasikan alat tersebut. Mengenai kelayakan finansial akan dibahas secara mendalam pada bagian kelayakan usaha perikanan tangkap.

\subsubsection{Analisis Aspek Sosial}

Penilaian terhadap masing-masing kriteria dalam aspek sosial, yaitu penyerapan tenaga kerja, pendapatan nelayan per unit per orang per tahun dan kemampuan nelayan dalam menjangkau investasi unit penangkapan ikan disertai dengan urutan prioritasnya, dapat dilihat pada Tabel 8.

Tabel 7. Nilai Masing-masing Kriteria dalam Kelayakan Finansial dari Setiap Unit Penangkapan Ikan di Kec. Leihitu

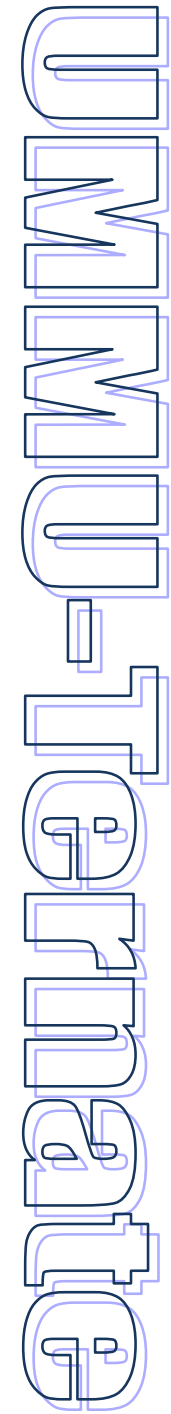

\begin{tabular}{lccc}
\hline \multirow{2}{*}{ Unit Penangkapan Ikan } & \multicolumn{3}{c}{ Kriteria } \\
\cline { 2 - 4 } & $\mathbf{X}_{\mathbf{1}}$ & $\mathbf{X}_{\mathbf{2}}$ & $\mathbf{X}_{\mathbf{3}}$ \\
\hline Gillnet & $141.250 .812,4$ & 1,897764619 & 55 \\
\hline Purse Seine & $227.403 .701,9$ & 2,955189981 & 60
\end{tabular}

Keterangan :

$\begin{array}{ll}\mathrm{X} 1 & =\text { Net Present Value (Rp) } \\ \mathrm{X} 2 & =\text { Net Benefit-Cost Ratio (Net B/C) } \\ \mathrm{X} 3 & =\text { Internal Rate Of Return (\%) }\end{array}$

Tabel 8. Nilai Masing-masing Kriteria dalam Aspek Sosial dan Urutan Prioritas dari Setiap Unit Penangkapan Ikan di Kec. Leihitu.

\begin{tabular}{ccccccc}
\hline \multirow{2}{*}{ Unit Penangkapan Ikan } & \multicolumn{7}{c}{ Kriteria } \\
\cline { 2 - 8 } & $\mathbf{X}_{\mathbf{1}}$ & UP & $\mathbf{X}_{2}$ & UP & $\mathbf{X}_{3}$ & UP \\
\hline Gillnet & 4 & 2 & $3.265 .362,5$ & 2 & 0,051 & 2 \\
\hline Purse Seine & 7 & 1 & 6.008 .000 & 1 & 0,06 & 1 \\
\hline
\end{tabular}

Keterangan :

$\mathrm{X} 1=$ Penyerapan tenaga kerja (orang)

$\mathrm{X} 2=$ Pendapatan nelayan per unit per orang per tahun (Rp)

$\mathrm{X} 4=$ Kemampuan nelayan dalam menjangkau investasi unit penangkapan ikan (\%)

$\mathrm{UP}=$ Urutan Prioritas

Penilaian pada kriteria penyerapan tenaga kerja menempatkan purse seine pada urutan prioritas pertama dan gillnet pada urutan kedua. Penilaian terhadap pendapatan nelayan per unit per orang per tahun menempatkan gillnet pada urutan prioritas pertama, dan purse seine pada urutan kedua. Sedangkan pada penilaian terhadap kemampuan nelayan dalam menjangkau investasi unit penangkapan ikan menempatkan gillnet pada urutan prioritas pertama dan purse seine pada urutan kedua.

Hasil penilaian aspek sosial secara keseluruhan dengan menggunakan fungsi nilai yang mencakup ketiga kriteria di atas, diperoleh hasil sebagaimana terlihat pada Tabel 9. Urutan prioritas pertama adalah gillnet dan purse seine pada urutan kedua. 
Tabel 9. Penilaian Aspek Sosial Secara Keseluruhan dengan Fungsi Nilai dari setiap Unit Penangkapan di Kec. Leihitu

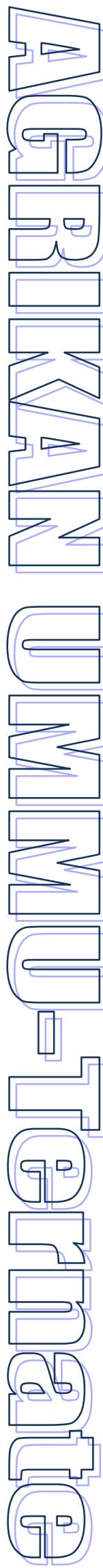

\begin{tabular}{|c|c|c|c|c|c|}
\hline \multirow{2}{*}{ Unit Penangkapan Ikan } & \multicolumn{3}{|c|}{ Kriteria } & \multirow{2}{*}{$\mathrm{V}(\mathrm{X})$} & \multirow{2}{*}{ UF } \\
\hline & $V\left(X_{1}\right)$ & $\mathrm{V}\left(\mathrm{X}_{2}\right)$ & $\mathrm{V}\left(\mathrm{X}_{3}\right)$ & & \\
\hline Gillnet & 0 & 0 & 0 & 0 & 2 \\
\hline Purse Seine & 1 & 1 & 1 & 3 & 1 \\
\hline
\end{tabular}

Penilaian aspek sosial secara keseluruhan setelah distandardisasi dengan menggunakan fungsi nilai, maka gillnet merupakan alternatif terbaik untuk dikembangkan. Hal ini dikarenakan jumlah pendapatan bersih nelayan per tahun dinilai paling tinggi bila dibandingkan dengan alat tangkap purse seine. Hal ini diduga karena ukuran alat tangkap yang dioperasikan tidak terlalu besar dan jumlah tenaga kerja yang terlibat dalam pengoperasian gillnet hanya 1 orang, sehingga pendapatan yang diterima nelayan cukup besar. Berdasarkan pendapatan yang diterimanya, kemampuan nelayan dalam menjangkau investasi unit penangkapan gillnet dinilai cukup besar bila dibandingkan dengan alat tangkap purse seine yaitu $1,45 \%$.

Alternatif pengembangan selanjutnya adalah purse seine. Purse seine dinilai mampu menyerap tenaga kerja yang banyak, yaitu 15 orang. Jumlah tenaga kerja yang banyak ini turut di imbangi dengan jumlah produksi yang dihasilkan, sehingga jumlah pendapatan bersih yang diterima nelayan cukup baik, meskipun masih berada di bawah pendapatan nelayan gillnet. Kemampuan nelayan untuk menjangkau investasi unit penangkapan ikan purse seine dinilai paling rendah bila dibandingkan dengan gillnet, yaitu hanya sebesar $0,02 \%$. Hal ini dikarenakan jumlah investasi yang diperlukan untuk pengusahaan purse seine cukup besar, sehingga dinilai masih sulit untuk dijangkau masyarakat nelayan.

\subsubsection{Analisis Gabungan}

Penilaian secara keseluruhan atau gabungan dari aspek biologi, teknis, ekonomis dan sosial dilakukan dengan menjadikan nilai dari masing-masing aspek tersebut menjadi nilai kriteria baru. Nilai masing-masing kriteria dalam analisis gabungan semua aspek tersebut dapat dilihat pada tabel 10 .

Berdasarkan penilaian yang dilakukan dengan menggunakan fungsi nilai terhadap keempat aspek yang dijadikan sebagai kriteria baru tersebut, diperoleh urutan prioritas dari unit penangkapan ikan yang diseleksi sebagaimana tertera pada tabel 11 .
Dalam rangka peningkatan peranan perikanan tangkap terhadap pembangunan secara umum, maka penanganan proses-proses produksi perikanan perlu dilaksanakan dengan penerapan ilmu pengetahuan dan teknologi yang sesuai (Wisudo et al, 1994). Menurut Kesteven (1973), terdapat empat aspek yang harus diperhatikan oleh suatu jenis alat tangkap untuk dapat dikembangkan, yaitu:

(1). Bila ditinjau dari aspek biologi, pengoperasian alat tangkap tersebut tidak mengganggu atau merusak kelestarian sumberdaya perikanan.

(2). Secara teknis efektif untuk digunakan.

(3). Ditinjau dari aspek sosial dapat diterima oleh masyarakat nelayan.

(4). Secara ekonomi usaha tersebut bersifat menguntungkan.

Berdasarkan analisis keempat aspek tersebut secara keseluruhan dengan menggunakan fungsi nilai pada kedua jenis unit penangkapan ikan, purse seine memperoleh nilai tertinggi, sehingga menempati urutan prioritas pertama. Bila ditinjau dari hasil analisis yang telah dilakukan, maka cukup beralasan bila purse seine memiliki nilai yang lebih baik dibandingkan dengan gillnet.

Ditinjau dari aspek teknis, pengoperasian purse seine dinilai cukup efektif dalam meningkatkan produksi hasil tangkapan. Jenis ikan yang menjadi tujuan penangkapan alat tangkap ini adalah jenis ikan pelagis yang berkelompok dan berenang bebas serta hasil tangkapan umumnya dalam jumlah besar. Sehingga ukuran alat tangkap dan perahu/kapal yang digunakan relatif lebih besar bila dibandingkan dengan gillnet. Secara sosial penyerapan tenaga kerja dari unit usaha penangkapan purse seine cukup banyak, karena disebabkan ukuran kapal dan alat tangkap yang besar.

Aspek biologi, purse seine yang dioperasikan oleh nelayan di Kec. Leihitu termasuk alat tangkap yang kurang selektif, karena menggunakan mata jaring yang berukuran hanya 1 inchi $(25 \mathrm{~mm})$. Meskipun demikian, alat tangkap ini tidak mengganggu atau merusak 
ekosistim dasar laut, karena hanya dioperasikan di perairan bagian permukaan dan umumnya jauh dari pantai. Secara ekonomi, pengusahaan unit penangkapan purse seine termasuk usaha yang menguntungkan dan layak untuk dikembangkan.

Urutan kedua dalam analisis gabungan ini adalah gillnet. Ditinjau dari aspek biologi, gillnet dinilai paling selektif, karena menggunakan ukuran mata jaring (mesh size) yang paling besar dibandingkan dengan purse seine, yaitu sebesar 3 inchi $(75 \mathrm{~mm})$. Namun secara teknis, alat tangkap ini dinilai kurang efektif dalam pengoperasiannya, karena sifat operasinya yang pasif dan menunggu ikan terjerat pada alat tangkap serta nilai selektifitas alat yang tinggi, sehingga banyak ikan-ikan dengan ukuran tertentu saja yang dapat tertangkap dengan alat tangkap ini. Secara sosial, penyerapan tenaga kerja yang dilibatkan dalam pengoperasian gillnet tidak ada, karena ukuran perahu dan alat tangkap yang dioperasikan kecil, serta usaha penangkapan ini hanya bersifat sampingan (bukan mata pencaharian utama). Secara ekonomi unit penangkapan gillnet layak untuk dikembangkan.

Hasil analisis aspek biologi, teknis, ekonomis dan sosial terhadap kedua unit penangkapan ikan di Kec. Leihitu, maka pengembangan unit penangkapan ikan yang bertujuan untuk meningkatkan produksi dan pendapatan nelayan serta efektif untuk dioperasikan adalah purse seine. Sedangkan untuk pengembangan unit penangkapan yang bertujuan agar mudah dijangkau dan diterima masyarakat nelayan tanpa mengabaikan faktor pemeliharaan dan peningkatan kelestarian sumberdaya perikanan adalah gillnet.

Tabel 11. Penilaian Aspek Secara Keseluruhan dengan Fungsi Nilai Terhadap Unit Penangkapan Ikan di Kec. Leihitu

\begin{tabular}{|c|c|c|c|c|c|c|}
\hline \multirow{2}{*}{ Unit Penangkapan Ikan } & \multicolumn{4}{|c|}{ Kriteria } & \multirow{2}{*}{$V(X)$} & \multirow{2}{*}{ UP } \\
\hline & $V\left(X_{1}\right)$ & $V\left(X_{2}\right)$ & $V\left(X_{3}\right)$ & $\mathrm{V}\left(\mathrm{X}_{4}\right)$ & & \\
\hline Gillnet & 0 & 1 & 1 & 0 & 2 & 2 \\
\hline Purse Seine & 3 & 4 & 4 & 3 & 14 & 1 \\
\hline
\end{tabular}

\subsection{Kelayakan Usaha Perikanan Tangkap}

Hasil yang diperoleh dari penilaian kelayakan finansial terhadap unit penangkapan gillnet pada berbagai tingkat suku bunga sebagai discount factor sebesar $12 \%$ dan $143 \%$, pengusahaan gillnet dinilai menguntungkan dan layak untuk dikembangkan. Hal ini ditunjukan dengan NPV yang bernilai positif dan Net B/C > 1 serta nilai IRR pada NPV $=0$ tercapai pada saat tingkat suku bunga $142,80 \%$. Sedangkan pada saat discount factor sebesar $143 \%$, diperoleh NPV yang bernilai negatif. Secara keseluruhan penilaian kelayakan finansial menunjukkan bahwa usaha perikanan tangkap gillnet layak untuk dikembangkan di Kec. Leihitu Kabupaten Maluku Tengah.

Untuk unit penangkapan purse seine dari penilaian kelayakan finansial pada berbagai tingkat suku bunga $12 \%$ dan $64 \%$, pengusahaan purse seine dinilai layak untuk dikembangkan. Hal ini ditunjukkan dengan NPV yang bernilai positif dan Net B/C > 1 serta nilai IRR pada NPV $=0$ tercapai pada saat tingkat suku bunga 63,84 $\%$. Sedangkan pada saat discount factor sebesar $64 \%$, diperoleh NPV bernilai negatif. Secara keseluruhan penilaian kelayakan finansial menunjukan bahwa usaha perikanan tangkap purse seine layak untuk dikembangkan di Kec. Leihitu Kabupaten Maluku Tengah.

\section{PENUTUP}

\subsection{Kesimpulan}

Kesimpulan dari penelitian ini adalah :

1. Usaha perikanan tangkap yang dilakukan oleh nelayan di Kec. Leihitu Kabupaten Maluku Tengah tergolong perikanan rakyat dengan skala usaha masih kecil sehingga perlu dilakukan pengembangan guna meningkatkan produktifitas nelayan setempat.

2. Berdasarkan analisis yang dilakukan baik dari aspek biologi, teknis, ekonomis dan sosial terhadap kedua unit penangkapan ikan tersebut menempatkan purse seine pada urutan prioritas pertama dalam seleksi teknologi penangkapan ikan yang layak dikembangkan di Kec. Leihitu Kabupaten Maluku Tengah. Urutan prioritas selanjutnya adalah unit penangkapan ikan dengan menggunakan gillnet.

3. Alternatif jenis teknologi penangkapan ikan yang sesuai untuk dikembangkan di Kec. Leihitu Kabupaten Maluku Tengah berdasarkan penilaian aspek biologi, teknis, ekonomis dan sosial, purse seine dinilai layak dikembangkan untuk tujuan meningkatkan 
produksi dan pendapatan nelayan serta efektif dalam pengoperasiannya. Sedangkan gillnet dinilai baik untuk dikembangkan bila pengembangan teknologi pengkapan ikan bertujuan agar pengusahaan unit penangkapan ikan mudah untuk dijangkau dan diterima masyarakat nelayan.

\subsection{Saran}

Perlu adanya perhatian dari pemerintah daerah setempat terhadap prospek usaha penangkapan ikan di Kec. Laihitu Kabupaten Maluku Tengah dengan melakukan perbaikan dan pengembangan sarana dan prasarana penunjang usaha perikanan.

Selanjutnya perlu diusahakan adanya bantuan modal usaha kepada nelayan dalam bentuk bapak angkat guna meningkatkan peroduktifitas nelayan dengan mengembangkan teknologi yang sesuai dan sekaligus meningkatkan kesejahteraan masyarakat nelayan.

\section{DAFTAR PUSTAKA}

Anonim, 1987. Kumpulan Desain Alat Tangkap Tradisional. Direktorat Perikanan Semarang.

Barus, Badrudin dan Naamin. 1991. Prosiding Forum II Perikanan, Sukabumi 18-. 21 Juni 1991. Pusat Penelitian dan Pengembangan Perikanan.

Brandt, A.V. 1972. Revised and England Fish Catching Methods of the Word. Fishing News (book) Ltd. 23 Resement Avenue West by Fleet, Survey London.

Dinas Kelautan dan Perikanan Kabupaten Maluku Tengah. 2010. Laporan Statistik Perikanan Maluku

Fridman, A.L, 1988. Terjemahan Perhitungan Dalam Merancang Alat Penangkapan Ikan. Bagian Proyek Penangkapan Teknik Penangkapan Ikan Semarang. Balai Pengembangan Ikan. Semarang.

Monintja, D. R. dan Zulkarnaen. 1995. Analisis Dampak Pengoperasian Rumpon Tipe Philipine di Perairan ZEE Terhadap Perikanan Cakalang di Perairan Teritorial Selatan Jawa dan Utara Sulawesi. Laporan Penelitian (tidak di publikasikan), IPB Bogor.

Mangunsukarto, K,B. Mardiyanto dan T. Hestirianto . 1985. Modul Alat-Alat Penangkapan Ikan. Buku II : Desain Alat-Alat Penangkapan Ikan. Depdikbud. Proyek Sisidiksat BKS PTN INTIM-IPB-USAID/AED. Bogor.

Sadhori, N. 1984. Bahan dan Alat Penangkapan Ikan. Yasaguna. Jakarta.

Sadhori, N. 1985. Teknik Penangkapan Ikan. Angkasa. Bandung

Sudirman dan Mallawa, A. 1999. Metode Penangkapan Ikan, Bahan Pengajar Program Studi Pemanfaatan Sumberdaya Perikanan, Jurusan Perikanan, Fakultas Ilmu Kelautan dan Perikanan. Universitas Hasanuddin.

Wisudo, S.H., H. Sakai., S. Takeda., S. Akiyama and T. Arimoto. 2002. Total Lumen Estimation of Fishing Lamp by Means of Rousseau Diagram Analisys With Lux Measurement. Proceddings of International Commerative Simposium $70^{\text {th }}$ Anniversary of the Javanesse Society of fisheries Science. Fisheries Science Tokyo. 